\title{
The Effects of Service Quality, Image and Trust on Satisfaction and Its Impact on Syari' ah Bank Customer Loyalty in Palembang
}

\author{
Diah Isnaini Asiati \\ Sekolah Pascasarjana, Universitas Pancasila \\ Universitas Muhammadiyah Palembang, Indonesia \\ E-mail: diah_isnaini@yahoo.com
}

Wibowo

Universitas Prof. Dr. Moestopo (Beragama), Indonesia

Husein Umar

Institut Bisnis dan Informasi Kwik Kian Gie, Indonesia

Tony Sitinjak

Institut Bisnis dan Informasi Kwik Kian Gie, Indonesia

Received: January 10, 2019 Accepted: January 25, 2019 Published: March 15, 2019

doi:10.5296/ber.v9i1.14205 URL: https://doi.org/10.5296/ber.v9i1.14205

\begin{abstract}
The purpose of this study was to analyze the effects of service quality, image and trust in satisfaction and its impact on Syari'ah Bank customer loyalty in Palembang, Province of South Sumatra. The research design in this study used causal analysis which explained correlation variables of 3 Syari'ah Banks with 250 people as banking clients in Palembang. The sample selection used simple random sampling. This dissertation draft used primary data from questionnaire filled out by the respondents. The method of research used descriptive statistics and Structural Equation Modeling (SEM). The results showed that the customer satisfaction had significant impact on customer loyalty, customer trust had significant impact
\end{abstract}


on customer satisfaction, customer trust had not significant impact on customer loyalty, service quality had significant impact on customer trust, service quality has significant impact on customer satisfaction, service quality had significant impact on customer loyalty, service quality had significant impact on Syari'ah Bank Image, Syari'ah Bank image had significant impact on customer trust, Syari'ah Bank image had no significant impact on customer satisfaction, and Syari'ah Bank image had no significant impact on customer satisfaction. The descriptive analysis showed that the level of service quality, image, trust, satisfaction and customer loyalty had a positive level.

Keywords: Service quality, Image, Trust, Satisfaction, Customer loyalty.

\section{Introduction}

The study of Syari'ah Bank is mostly linked to the majority of Muslims in a country, including in Indonesia, although the Syari'ah Bank is actually a banking system that can be used by anyone. The idea of the emergence of Syari'ah Bank in Indonesia was starting in 1970, grew rapidly in 1998-2015, then slowed down until now (Syari'ah Bank Satistic Report).

Compared to non-syari'ah banks, the performance of Syari'ah banks in general is still far below the non-Syari'ah bank. The market of Syari'ah Bank nowdays has only reached 5.3\%, even though the number of customers is only $18.75 \%$ compared to conventional bank customers. Although it is not proportional to compare the performance of non-syari'ah banks with syari'ah banks, considering the age of growth is very different, but because the two banks play in the same market, automatically consumers and many related agencies will compare both.

Based on Syari'ah Banking Statistics (BI, 2009-2015), the growth of Syari'ah Banks in Indonesia has increased both financially and non-financially. However, in recent years this growth has slowed and tends to stagnate in view of the number of BUS, UUS, and LS that available. As a result, the target market share is still low. Several investigations conducted that showed low customer loyalty because 1) customers tended to let their accounts "sleep" as "wait and see" actions, while transactions were more actively carried out with other banks 2) Service qualityfor Syari'ah Bank was considered inferior to conventional banks, services, products, access, and comfort and cleanliness 3) the image of the syari'ah bank has not been convincing.

\section{Literature Review}

\subsection{Customer Loyalty}

The concept of loyalty is a dynamic concept. According to Greemler (1999) originally loyalty was only identified with satisfaction. At the next stage it turns out that being satisfied is not enough, loyalty is interpreted as the willingness of customers to survive making purchases. Furthermore, there was a growing understanding that loyalty must be accompanied by company proactive actions, including retracting running customers. Finally, loyalty will be meaningful if the customer is willing to refer and spread good news about the company. 
Edvardsson et.al. (2000) state that, loyalty is the intensity or tendency of consumers to repurchase to a particular company. Loyal consumers can reduce costs (Fornell, 1992) and give several benefits (Gee, et.al.2008).

Dimitriades (2006) states that, loyal consumers are consumers who have a pleasant attitude towards the organization, recommend the organization to others, and usually make repeat purchases. According to Griffin (2007) there are four characteristics to mark loyal customers, namely: 1) makes regular repeat purchases, 2) purchases across product and services lines, 3) refers other product, 4) demonstrates an immunity to the full of the competition.

In the banking industry, loyalty is an important aspect that must be obtained and maintained considering that banking transactions are not instantaneous transactions that are only connected by one type of product. The formation of customer loyalty is based on many other important aspects such as customer satisfaction, service quality, banking ideals, and customer trust. The study was carried out by Nayebzadeh, et al (2013) in Iran, Saeed, et al (2014) and Sabir (2014) in Pakistan, which proved that there was an effect of customer satisfaction on customer loyalty. This result was different from what was done by Badara et al. (2013) in Nigeria. Therefore the hypothesis was proposed:

H1: There was an effect of customer satisfaction on customer loyalty

H2: There was an effect of service quality on customer loyalty

H3: There was an effect of trust on customer loyalty

H4: There was an effect of image on customer loyalty

\subsection{Customer Satisfaction}

One of the factors that influence loyalty is customer satisfaction (Griffin, 2007). According to Kotler \& Keller (2016) customer satisfaction as feeling happy or disappointed someone who appears after comparing between perceived product performance with expected product performance. Bitner \& Zeithaml (2003) states that, satisfaction is the evaluation of consumers of products or services by comparing products or services that are needed as expected. Likewise stated by Hoyer \& Maclnnis (2001) that satisfaction is related to feelings of acceptance, happiness, relief, joy, and joy.

Although agreement was not obtained in measuring customer satisfaction, according to Chan \& Dubinski (2003), there are three aspects that need to be revealed in measuring customer satisfaction. First, overall satisfaction, which is commonly used in surveys and research as one indicator. Second, confirmation of expectations, namely the degree to which performance exceeds or equals expectations. Third, the comparison of ideal conditions, namely the relative performance of the ideal product.

In the banking industry, satisfaction is a necessity that is hard to disprove. The willingness of customers to survive to carry out transactions always comes from their satisfaction. When satisfaction is formed by many elements, satisfaction can also be identified from the elements forming overall satisfaction, such as service quality, trust, and image. An empirical study of 
customer satisfaction was carried out by Khafafa (2013) in Lybia, Sanjuq (2014) in Riyadh, Ahmed (2011) in Malaysia, Fouzia (2012) in Pakistan. Based on several studies, the hypothesis was formulated:

H5: There was an effect of service quality on customer satisfaction

H6: There was an effect of trust on customer satisfaction

H7: There was an effect of image on customer satisfaction

\subsection{Trust}

Trust is one element that determines customer satisfaction (Engel, 2016). According to Mollering (2006) trust is a psychological state consisting of the desire to accept an unpleasant situation based on positive expectations of the wishes or behavior of another party. The formation of hope takes time because the basic material is accumulated experience even though the experience is events that do not necessarily describe the object as a whole.

In the context of the relationship between producers and consumers, Schiffman \& Kanuk (2008) suggests that trust is the belief of one party regarding the intentions and behavior of the other party. Then Gronroos (2000) calls trust as credibility. Credibility shows the extent to which buyers believe that suppliers have the expertise to carry out activities effectively and reliably. Trust relates to the company's intention to rely on their exchange partners. In addition, trust is also a benevolence, because it is based on the degree to which the company believes that its partners have beneficial intentions and motives.

Robbins and Judge (2009) mention at least four key dimensions in the concept of trust, namely: (a). Integrity, refers to honesty and truth; (b). Competence, related to knowledge and technical and interpersonal skills possessed by individuals; (c). Consistency, related to reliability, predictability, and appropriate assessment of individuals in handling situations; (d). Openess. According to De Vito (2001) openness refers to three aspects of interpersonal communication, namely; willingness to self-disclosure adequately, willingness to act honestly with other people's messages, have feelings and thoughts.

The banking industry is an industry of trust, without trust it is impossible to expect a bank to develop. The customer does not have knowledge about how the bank will manage the funds that are handed over, however the willingness of customers to submit is always accompanied by the belief that the funds are safe and will grow. The relationship between trust and service quality and banking image has been verified by Irwan Misbach (2013) and Rahmani, et al (2014). Guranyameh (2015) connects trust with image. Therefore, a hypothesis is formulated

H8: There was an effect of service quality on trust

H9: There was an effect of image on trust

\subsection{Image}

Image is one of the determinants of corporate differentiation (Kotler \& Keller, 2016) so that it becomes a decision maker and customer loyalty. According to Kotler and Keller (2016), 
image is a set of beliefs, ideas, and impressions that someone has towards an object. Dowling (1994) in Engel et.al. (2016) defines the image as "the total impression of an entity making on the mind of people". When this is implemented, there are three types of images that can be identified, namely: 1) Corporate image, which is a view of the community towards the entire company, 2) Product image, which is a view of the product or product category, 3) Brand image is a public view of the brand of a product.

In measuring corporate image, Spector (2005) found that there were six main factors used to measure the main dimensions of organizational image, namely: (a) Dynamic, namely in terms of pioneers, attract attention, active, goal oriented; (b) Collaborate, namely in terms of friendliness, likes, makes other people happy, has good relationships with other people; (c) Business, namely in terms of wise, smart, persuasive, organized; (d) Character, namely in terms of ethics, reputation, respect; (e) Success, namely in terms of good financial performance, trust; and (f) Resist: strict, keep secret, be careful.

The Image has never been formed in a short time and has no achievements. An image is a market verification of good achievements that occur continuously. Therefore, in the world of banking, the image contributes greatly to the formation of customer trust. The image in question can be seen through the total services provided by banks. Warsito (2015) conducted a study of the effect of service quality on partners. That is why the hypothesis is formulated:

H10: There was an effect on service quality on image

\subsection{Service Quality}

According to Khalid (2011) service quality is a general opinion related to the quality and superiority of service organizations. Service quality involves activities that are generally not real, involving the interaction of customers and service servants using complete physical facilities and provided to consumers as a solution to their needs. Service quality is a marketing stimuli of companies, especially service companies.

In 1988, Parasuraman et al. (1988) conducted qualitative research using an instrument to measure consumer perceptions of service quality, then known as SERVQUAL. Research summarizes its dimensions from ten to five. These dimensions were;

a. Reliability (reliability), namely the ability provides services that are promised precisely (accurately) and the ability to be trusted (dependably), especially providing services in a timely manner (ontime) in the same way in accordance with the promised schedule and without making mistakes.

b. Responsiveness, namely the willingness and desire of employees to help and provide the services needed.

c. Assurance, including knowledge, ability, friendliness, courtesy, and trustworthiness of personnel contacts to eliminate the doubtful nature of consumers and feel free from danger and risk.

d. Empathy, including personal and company contact attitudes to understand the needs and 


\section{Macrothink}

Business and Economic Research

ISSN 2162-4860

2019, Vol. 9, No. 1

difficulties of consumers, good communication, personal attention, ease of communication and relationships.

e. Tangibles (physical form of the product), the availability of physical facilities, equipment, and means of communication that can and must be in the service process. Assessment of this dimension can be expanded in the form of relationships with other consumers of service users, such as the commotion made by hotel guests.

\section{Research Method}

This study used a causal design (Malhotra, 2007). Empirically testing was performed using the customer answers that were derived from Syari'ah BNI, Syari'ah BRI and Syari'ah Mandiri in Palembang. The first questionnaire was obtained from 30 respondents as a pre-test. The results of pre-test showed that all indicators proved to be valid. All variables also proved to be reliable because it had a Cronbach's alpha> 0.7 (Nunnaly, 1978). Furthermore, the second questionnaire were distributed proportionately to 250 customers selected by systematic sampling. The study tried to see the connection between some of the variables as figure 1. Tests on the relationship between these variables was performed using structural equation modeling software lisrel.

\section{Findings and Discussions}

The results of data processing was shown in the following table:

Table 1. Test Results Model

\begin{tabular}{|l|l|l|l|l|}
\hline No. & Test & Standard Values & Values obtained & result \\
\hline 1 & Chi Square & $<0.05$ & 0.05 & Fit \\
\hline 2 & RMSEA & $<0.08$ & 0.08 & Fit \\
\hline 3 & GFI & $>0.9$ & 0.93 & Fit \\
\hline 4 & AGFI & $>0.9$ & 0.93 & Fit \\
\hline 5 & NFI & $>0.9$ & 0.73 & Unfit \\
\hline 6 & CFI & $>0.9$ & 0.78 & Unfit \\
\hline 7 & IFI & $>0.9$ & 0.79 & Unfit \\
\hline 8 & RFI & $>0.9$ & 0.68 & Unfit \\
\hline 9 & ECVI & 7.15 & 1.81 & Fit \\
\hline 10 & AIC & 7.15 & 1.81 & Fit \\
\hline 11 & CAIC & 2082.32 & 501.90 & Fit \\
\hline 12 & PGFI & $>0,60$ & 0.65 & Fit \\
\hline 13 & RMR & $>0.1$ & 0.13 & Fit \\
\hline
\end{tabular}

There were nine of 13 passes in the test element models, thus it could be said that research model was fit and further analysis could be forwarded. Data processing of $t$ statistical and each coefficient values shown in the following figure 2 . 


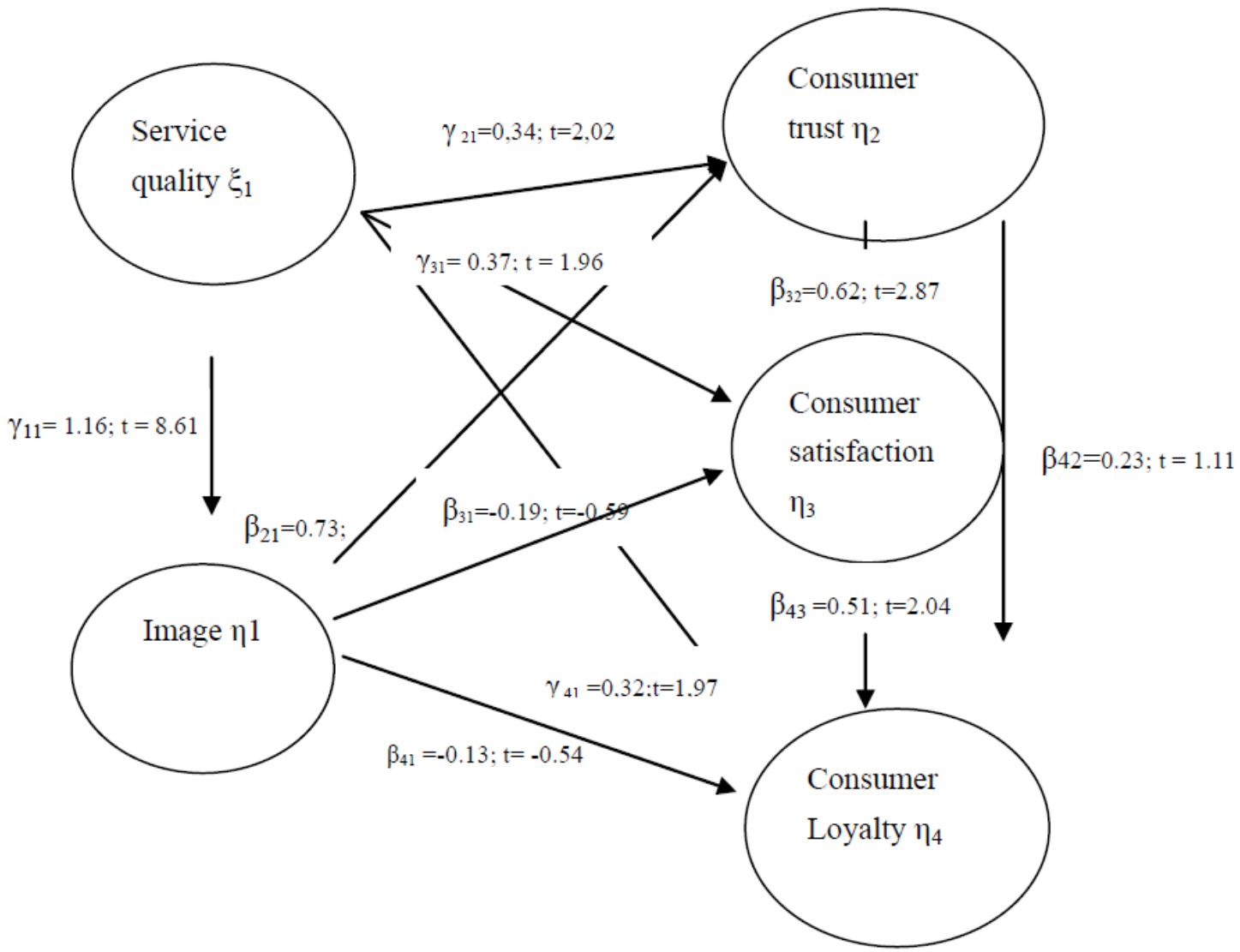

Figure 1. Complete Model Results

The complete model was shown summarized as followed:

Table 2. Results of Hypothesis Testing

\begin{tabular}{|c|c|c|c|c|c|}
\hline hypothesis & & coefficient & T count & p-value & Decision \\
\hline Service quality & $\rightarrow$ Image & 1.16 & 8.61 & & Ho rejected \\
\hline Service quality & $\rightarrow$ Trust & 0.34 & 2.02 & & Ho rejected \\
\hline Service quality & $\longrightarrow$ Satisfaction & 0.37 & 1.96 & & Ho rejected \\
\hline Service quality & $\rightarrow$ Loyalty & 0.32 & 1.97 & & Ho rejected \\
\hline Image & $\longrightarrow$ Trust & 0.73 & 3.1 & & Ho rejected \\
\hline Image & $\longrightarrow$ Satisfaction & -0.19 & -0.59 & & Ho accepted \\
\hline Image & $\longrightarrow$ Loyalty & -1.16 & 0.54 & & Ho accepted \\
\hline Trust & $\longrightarrow$ Satisfaction & 0.62 & 2.87 & & Ho rejected \\
\hline Satisfaction & $\longrightarrow$ Loyalty & 0.51 & 2.04 & & Ho rejected \\
\hline Trust & $\longrightarrow$ Loyalty & 0.23 & 1.11 & & Ho rejected \\
\hline
\end{tabular}

The following discussion of each of the linkages between these variables:

\subsection{The Effect of Customer Satisfaction on Customer Loyalty}

Customer satisfaction proved to have a significant effect on customer loyalty Syari'ah bank. This fact empirical evidence that the banking services, customer satisfaction became an important base of customer loyalty formation. Customer satisfaction meant customer 
expectations that meet through banking performance that was good even exceeded his expectations. These conditions give rise to a feeling of acceptance, happiness, relief, excitement, and joy (Hoyer \& Maclnnis, 2001) so as to encourage customers to continue to be able to obtain the same feeling with the repurchase. Repurchasing sustained showed of customer loyalty. Loyal customers inclined to make purchases on a regular basis, developed a positive story from mouth to mouth, and showed resistance to competitors' products.

Some previous studies had proved the influence of satisfaction on customer loyalty, Siddiqi (2011), Nayebzadeh et.al (2013), Sabir et.al (2014), and Kashif et. al (2015). Only Badara et.al (2013) and Munawar Khan (2014), which provides evidence that there was no significant effect of satisfaction on customer loyalty. The results of Badara et.al (2013) distinction is possible because the survey carried out on Nigerian students who were taking classes in Malaysia. Banking services that they received in their home country might be different than the service in Malaysia as a result of various differences in the atmosphere, the availability of facilities, services and other employees, causing a different feeling which resulted in discontent that eventually became disloyal. The results of this study reinforced the findings of several previous empirical studies.

In this research, customer loyalty should be maintained and enhanced so that the cause of pride. Formation / increase customer loyalty needed because the majority of the respondents $(41.2 \%)$ had $1-3$ years as a customer, even $25.2 \%$ had under one year as a customer. Only $16 \%$ had more than 5 years as a customer.

\subsection{The Effect of Customer Trust on Customer Satisfaction}

Customer trust shown to have a significant effect on customer satisfaction syari'ah bank. These findings provided information that customers had trust in the syari'ah bank so satisfied. Customers believed that syari'ah bank being honest and true force in setting the rules applicable banking transactions. The rules were believed to have been in accordance with the principles of syari'ah and developed according to the needs/wants of customers. In addition, customers also believed that the syari'ah bank employee had an employee who had knowledge relating to Islamic banking products and services.

The banking business was a business of trust, therefore the willingness of customers trust underlying transaction. Furthermore, trust was strengthened by the consistency of syari'ah bank in providing services, provided for the results, provided information, and being proactive with customers. Consistency was further strengthening customer trust so the impact on satisfaction.

Effect of customer trust in the satisfaction never been substantiated by Hidayat et al (2015) and Rahmat Madjid (2015). Hidayat used measurements of different beliefs than this study, while Rahmat Mandjid using the same relative measurements even equally done in syari'ah BNI, syari'ah Mandiri and syari'ah BRI, and both give the same result. This meant that the results of this study reinforce the two previous findings.

Anchored by the banking conditions in Indonesia, supported trust in the banking activity was getting stronger with the Indonesian Government Regulation No.39 On October 12, 2015 
concerning the Deposit Guarantee Customers Based on the syari'ah principle. Since October 13, 2008 balances were guaranteed for each customer in one bank was Rp 2 billion (www.lps.go.id). This regulation added customer trust in the banking transaction in which further influence on satisfaction.

\subsection{The Effect of Customer Trust on Customer Loyalty}

Trust was directly proved no effect $(0.23)$ on loyalty, though indirectly (through customer satisfaction) significantly (0.32) on loyalty. When consumers believed the product / service company or brand, then it would help the formation of consumer loyalty and generated word of mouth stories that were positive (Kasim and Abdullah, 2010). Therefore, when the customer believed the product / banking services should establish customer loyalty. According to Hidayat and Akhmad (2015) some aspects affecting the loyalty was satisfaction, emotional ties, trust, reduction choices and habits, and the company's history.

The results of this study proved the trust had no effect on loyalty. Syari'ah bank clients apparently had not fully trust syari'ah bank, though the discussion of the variables did not reveal any trust indicator that was problematic. It could be explained, first, the length of the achievement of the targeted market share of syari'ah bank actually indirectly indicated that customer trust was still low. Secondly, it was likely there were other indicators beyond those used in this study that was the basis of customer trust. Several indicators developed from the dimensions of integrity, competence, consistency, and openness in this study were indicators became standard banking operations. The trust was believed to be the customer that might involve differences in principle than conventional bank, that syari'ah bank was downright promising secure transactions, fair, blessing, promising tranquility, and others. Note appointment of Syari'ah bank through its motto; (1) Syariah BNI: provided the best fit creed; (2) Syari'ah Mandiri: good things starting from a good place; (3) Syari'ah BRI: together achieve shared expectations.

The character could not be fully controlled banks, but also required an understanding of the customers personally. Nevertheless, it remained the duty of the syari'ah bank to attempt to show the performance that could generate customer trust. Proving quality was consistently and continuously created trust.

Some of the results of similar studies conducted by Hassan et.al (2012), Kishada et.al (2013), Rizwan et.al (2014), Hidayat dan Akhmad (2015), and Ashraf (2015) provided evidence that different, that trust significant effect on consumer loyalty. The yield difference against some of the arguments put forward were:

a. Most locations previous research conducted in Pakistan and Malaysia, where the development bank was known beforehand Syari'ah (1970) so that the performance history of Syari'ah banks had long been known and inflict more stronger trust to cultivate loyalty. Government support and commitment to its development also strengthen the enforcement of Syari'ah banking system. The study was conducted in Indonesia, where the market share of Syari'ah banks to had reached 4.8\% (November 2016 had reached 5.3\%). The history of syari'ah bank was much shorter (starting 1990) compared to the growth and development of 
conventional banks (two centuries). Naturally, if the market still demands a lot of evidence beforehand to show loyalty to the syari'ah bank. Judging from the characters seem too different customers. Customers in Pakistan and Malaysia over their Islamic militant than in Indonesia, despite the fact that Syari'ah Bank intended not only to Islamists.

Hidayat and Rakhmad (2015) conducted research in Indonesia (East Java) and proved a significant effect of trust on loyalty. This was possible because East Java was one basis Syari'ah bank market. Although banks Syari'ah developed using the principles of Syari'ah could not only be used by Muslims, but the Islamic mass linkages with the principles of Syari'ah in Indonesia difficult to separate.

Thus the results of this study provided information that the market still needs more proof of his faith obtain satisfaction through the transaction to have a loyalty to the Syari'ah bank.

b. All previous studies (except Rakhmad and Hidayat) used multiple linear regression analysis techniques, whereas this study and Rakhmad and Akhmad used SEM analysis techniques. Difference analysis technique also allowed for differences in the results.

To foster a belief impact on customer loyalty, then the bank's Syari'ah be charged consistently provided proof of promises that expressed either explicitly or implicitly. Explicitly, these promises expressed in various moto and syari'ah bank ad (the good stuff starts from a good place, trustful partners building area, the first pure Syari'ah, and others). -implicitly promises could be seen from the appearance of employees, religious symbols were in each office / transaction room, as well as the name and the meaning of a variety of products / services offered). This consistency was in the long term to establish customer loyalty and had loyal clients who were ensuring the survival of the company.

\subsection{The Effect of Service quality on Customer Trust}

Variable service quality in this study proved a significant effect on customer trust Syari'ah bank. Service quality was the overall service quality received by the customer after the transaction with syari'ah bank. The service quality is very important that is forming a satisfaction and consumer trust ((Nejad et.al, 2014). In a lot of research on service quality in banks, hospitals, and various business services, service quality was proven effect on satisfaction. Increased consumer perceptions of service quality would affect the various qualities of relationship satisfaction and trust.

Customer trust would arise if syari'ah bank could show the service quality as proof of its promises. The more consistent and long this process would strengthen the trust of customers, so customer trust could be built through the provision of service excellence. Service was an important factor in the service industry, including banking. Service quality was the service that was reliable, responsive, had a guarantee, empathetic, and supported by adequate means. Every customer who came of course hoped to receive these characteristics, skilled employees, quick to respond, amenities created a comfortable, smooth transaction, and fun.

Previous research had been conducted to prove the relationship of these two variables. Misbach et al (2013) proved that the service quality (consisting of responsiveness, reliability, 
compliance, and system) had no significant effect on trust. While Rahmani et.al (2014) gave the significant effect of service quality on customer trust. Thus the results of this study supported the results of Rahmani et.al (2014), but contrary to the results of Misbach (2013). This difference could be traced to the characteristics of the customer. Characteristics of customers in this study and Misbach had many similarities, including the majority of customers that were all females, age of the customer was the same majority (range 30-40 years), and education customers were similarly dominated by scholars. However, visits by revenue, the two studies in striking contrast, the majority of customers in this research income of Rp 3,000,000, - - Rp 6.000.000, - while the customer revenue in Misbach study conducted in South Sulawesi ranging from Rp 5,000,000, - - Rp 10.000.000, -. Consumers with higher incomes generally had a steeper demands in terms of products / services. The high demands of our customers for service quality in the study of Misbach caused these variables had a relatively small effect (not significant) towards customer trust. In addition, although both studies using the same analytical techniques (SEM), the difference in the number of samples used and developed service quality indicators also might contribute to the differences in the results.

These results lend support to the importance of demonstrating quality services in order to foster customer trust in the banking industry. Various service quality provided syari'ah bank that would establish the level of customer trust. High quality services would build customer trust in the superior performance of banks, and vice versa. It should be noted the existence of the questions in the variable quality of the service in question, namely: (1) Customers were not easy to find the location of the branch unit syari'ah bank; (2) Customers were not easy to find the location of syari'ah bank ATM. Therefore Syari'ah bank had to: (a) Continue the program to expand the market. The breadth of the market could increase market share and boost its growth. If the market growth so the Syari'ah bank could immediately add locations by opening more branches. The more branches established, the more the markets served, more and more ATMs were provided, it would provide better benefits and ensure the continuity of its business development; and (b) Conduct monitoring and evaluation of the quality service. Along with the changes in the environment, customer demanded on the service quality might be changed so that the Syari'ah banks also had to adjust its performance. This action would provide valuable lessons for adaptive to the environment, the more solid the more adaptive to survive in an atmosphere of competition. These strengths would provide a great contribution to profit for the company's survival in the future.

\subsection{The Effect of Service quality on Customer Satisfaction}

This study empirically proven that affect the service quality satisfaction, either directly $(0.37)$ and was mediated by the trust variables $(0.21)$. No doubt service quality growth as essential in the banking industry (Munusamy, et.al, 2010). Service qualityand customer satisfaction were related, high service quality which resulted in high satisfaction. There was no agreed standard measure for determining quality in the banking sector. Syari'ah bank profits obtained through the high service quality that was an important step to survive. High-quality services that had result in the fulfillment of the performance of Syari'ah bank in view of its customers exceeded expectations before making a transaction. The performance exceeded 
expectations leads to customer satisfaction.

Measuring the service quality seemed difficult for marketer's services due to unique characteristics of the service itself such as intangibility, inseparability, variability, and perishability (Kotler \& Keller, 2016). Research of service quality was increasingly important due to the emergence of service quality with various aspects such as cost, profitability, customer satisfaction, the survival rate of the consumer, and a positive story of mouth (Munusamy et.al, 2010).

Many studies about the relationship of service quality and customer satisfaction had been done before. Munusamy et.al (2010), Darmansyah (2011), Ahmed (2011), Ramdhani et.al (2011), Salman Khalid (2010), Khafafa et.al (2013), and Sanjuq (2014). All of them provided evidence that the service quality was the result of a significant effect on customer satisfaction. The results of this study reinforced previous research that a number of results. Therefore, it was important to realize the services quality of Syari'ah bank service quality. Repairs to the indicators that undermine the service quality might be carried out even though the repair techniques could not be directly granted.

As mentioned in the foregoing discussion, in a systematic marketing strategy that needed to be done was:

a. Determining the market segment. In terms of segmenting, banking transactions were transactions that involved all segments of geographic, demographic, psychographic, and behavioral effects. Syari'ah bank despite operated using the principles of Syari'ah, but the target market was not a market that was specific to Islam, the concept of syari'ah in banking practiced accessible to the anything. Therefore, basically the use of mass marketing could be done. Financial Services Authority (FSA) said today, total Islamic banking customers reached approximately 15 million inhabitants. Meanwhile, the conventional banking customers to touch about 80 million people. Compared with conventional banks, the total new Islamic bank customers reached 18.75 percent

(http://www.beritasatu.com/ekonomi/306719-nasabah-bank-syariah-1875-persen-dari-total-k onvensional.html). Mini Figures showed the huge market potential Syari'ah bank.

In terms of targeting, Syari'ah bank customers could be grouped into three targets, namely pure Syari'ah customer, the customer was moderate (using transaction Syari'ah and conventional) and non-Syari'ah segment. Each target needed a different strategy. The first target, needed to be maintained to provide maximum service quality so that loyalty could be built. Two final targets needed to keep educated through sharing of information and services to made access to appear willingness to transact.

In terms of positioning, Syari'ah bank needed to remain committed to the values that it carried while continuing to align the entire performance with conventional banks.

b. Socialization. The magnitude of the potential market faced by banks Syari'ah required banks to remain aggressive with its communication activities. A wide variety of promotions could be designed to encourage prospective customer appeal more. Cooperation programs continued to be built and developed. Based on interviews, cooperation in the form of 
employee compensation payments and tuition was pretty much increased the number of customers. Furthermore, these partnerships should be maintained continuity by providing the best quality services.

c. Internal improvements. This step was a step that was no less strategic. There was no point hook the broad market but minimal in management. This step was a job that was heavy enough to syari'ah bank because it might compete with conventional banks. HR needed to be improved performance in order to better appreciate the principles of Syari'ah, the service quality should also be evaluated periodically to ensure that the client had obtained the best. If the market extended the addition of facilities and meant necessary to provide easy access for customers.

d. Increase cooperation. This step would facilitate the efforts above, enlarged the market, socialized, and made improvements internally. Did good cooperation with other institutions fields (schools, companies, government agencies) as well as the institution of a parcel (the same financial institution). It should be noted that rated financial institution rapid growth (Rural Bank / BPR for example). When seen growth, there were several BPR considered successful. BPR usually operated in a narrower region that was "more personal" provided financial services. Although both required procedures to be customers, but the procedure was owned BPR easier / simpler than the bank, so the strategy of "proactive" it was relatively successful.

\subsection{The Effect of Service quality on Customer Loyalty}

The results of testing this hypothesis proves there is significant influence of service quality on customer loyalty, either directly (0.32) as well as through customer satisfaction variables (0.19). Measuring the quality of services to benefit the company (Kashif, 2016), a low cost in the long term, a high loyalty, and increased market share. One popular measure is a widely used SERVQUAL (Parasuraman, 1985). Five dimensions in the scale SERVQUAL is reliability, responsiveness, assurance, empathy, and tangibles. Customers are always comparing the service qualitythey expect from a syari'ah bank before engaging in transactions with the quality of the services actually received after the transaction. If the service qualityis consistently always felt so customers will feel happy and repeat transactions. In the long term this transaction repetition becomes a source of customer loyalty. Loyal customers will always told good things about the bank syari'ah, continued to perform the transaction, even with diverse types of transactions, and were not easily attracted by the offer of a competitor.

When it viewed from syari'ah bank service quality based on its dimensions, responsiveness, reliability, and assurance was considered good by its customers. Based on interviews with several customers, clients generally considered that the Syari'ah banking services were already well as non Syari'ah banking services. How to bank officers providing service, hospitality, handling problems, and communication was generally not problematic. On the quality of these services was a customer complaint on tangible dimension, facilities and infrastructure were still considered inadequate. ATM number and location of branches / sub-branches spreading were still unwell. 


\section{Mll Macrothink}

Business and Economic Research

ISSN 2162-4860

2019, Vol. 9, No. 1

The dimensions of empathy, evaluation needed to be done. According to the customer, customer service procedure in Syari'ah bank that had been good, officials said hello as he pressed both hands, airport, asking his needed to another, until finally saying hello back. The procedure was done repeatedly so that the pronunciation was then impressed officer more formality and not sincere. This was what might be considered less empathy by the customer.

Some previous researchers had studied the relationship these two variables, Kheng et.al (2010), Butt \& Aftab (2013), Sunaryo (2013), and Kashif \& Rehman (2016). Everything gave the results prove that, the service quality effect on customer loyalty. These results provided support for the results of previous studies. Furthermore, these results also proved that the dimensions quality proven service could create customer loyalty Syari'ah bank. The customer had a good feel and assess the availability of physical facilities Syari'ah bank, bank reliability Syari'ah, the response of employees in service, the bank guarantee given Syari'ah, and empathetic attitude of employees towards customers.

Interesting to explore further, in this study turned out to be a direct effect of service quality on customer loyalty had a value greater than its indirect effect via variable customer satisfaction. Whereas in some previous research, consumer satisfaction variables successfully mediated the effect of greater customer loyalty. This meant that in this study to be a loyal bank customers syari'ah, did not need to be satisfied first. Based on interviews with respondents, this fact appeared because Syari'ah bank customers generally were not customers who join the initiative and his own volition but because the system demanded that indeed they might follow (credit procedure, the doors' salaries, school payments, etc.), Unfortunately, this study did not cover what percentage of customers who joined in Syari'ah bank for various reasons above. If this fact was true then it would be important for Syari'ah bank to evaluate and improve the quality of its services in order to increase the satisfaction of customers.

\subsection{The Effect of Service Quality on Image}

Research showed that the service quality was a significant effect on the image of Syari'ah bank in Palembang. High competition in the banking industry was indirectly into force banks to constantly evaluate and improve service quality. Each Syari'ah bank were required to provide maximum service quality as good or bad banking services determine how many customers got the actual service.

Good service quality was to form a positive impression in the minds of customers, especially when the service quality transactions were received and perceived by the customer repeatedly over a long period. Repetition of a consistent service quality that would form a positive impression in the minds of customers so that a lot of positive assessment relating to the products / services, transaction processing, services, competition, and others. The impression that underlied the emergence of the image. The image of an important part of the marketing activities that should always be maintained and repaired.

Research that links between the service quality with the bank's image was made by Warsito Syari'ah (2015). Research results proved that, the service qualitywas a significant effect on the image. This influence would be greater with customer satisfaction as the intermediary. In 
this study, the image was also a mediating influence on satisfaction of service quality, and the result was not significant. It meant that the image actually reduced customer satisfaction on Syari'ah bank. Therefore important for banks Syari'ah to continuously evaluated and repaired the service quality. Service quality would establish a good image of Syari'ah bank in the minds of customers. The image formation simply could not be done instantly, the image was formed through the company's long experience interaction with customers. During that time, repeatedly tested quality services by customers in a variety of situations and time so there was no doubt the customer in providing testimony that the Syari'ah bank was a qualified bank

\subsection{The Effect of Image on the Customer Trust}

The research proved that Syari'ah banking image effected on customer trust. The results of previous studies that supported this research model corporate image influence on customer trust. The theory states that the image is a set of beliefs, ideas, and one has the impression of an object (Kotler \& Keller, 2016). When it was implemented, there were three types of images that could be identified, namely: 1) The image of the company, namely a society's view of the whole enterprise 2) The image of the product, namely a society's view of a product or product category 3) brand image was a society's view of the brand of a product.

Why would affect the image of trust? So far, customers of Syari'ah banks did have trust in syari'ah bank. Descriptive analyzes also indicated no issues with the variables of trust, and it turned out the customer trust due to its image. It was thus important for Syari'ah bank to build its image. Syari'ah bank age was relatively young that was still difficult not to recognize the power of image. This meant that Syari'ah bank still took much longer to show consistency service quality to the market so that Syari'ah banks might work harder to show a better image. Syari'ah banking companies might work to improve its image as a bank that actually run the Islamic law and professional worked in order to grow, so that the public's view of Islamic banking could be improved overall.

On the other hand, Syari'ah banking products offered to the potential market should be able to move people's desire to be willing to do a purchase decision on bank products offered. The role of the marketing department was very high for the achievement of consumers' purchasing decisions, despite the fact that promotional obligations was the duty of all member banks. With the success of the sales of the products offered, then the image of Syari'ah banking product was better. With the image of the movement banks were improving, then at a certain side effect would look good corporate image on customer satisfaction and customer loyalty.

The image had significant effect on customer trust in Syari'ah bank. In his journey, these beliefs would form the satisfaction leads to customer loyalty. Direct effect on satisfaction and loyalty image was not significant, but when mediated by the trust, the image effected on consumer satisfaction amounted to 0.23 and 0.12 on customer loyalty. These results demonstrated the importance of trust in the banking business. Banking transactions were transactions with barriers to entry and exit that are relatively high and sustained over the long term. Customers decided to bind themselves to the Syari'ah bank in relation to the 
management of the funds that were not risk-free. Under these conditions, customers wanted assurance that its one manifestation was visible. Basic trust was a long experience of Syari'ah banking performance on the service quality which was reflected through the image.

The effect of image on the customer trust in Guranyameh study (2015). In that study, image power could be identified through the experience of consumers $25-34$ and some $48 \%$ had transaction experience for over 5 years. In this study, the majority of respondents age were $30-40$ years, but the customer experience transacting was less than one year $(25.2 \%)$ and between $1-3$ years $(42.2 \%)$, only $16 \%$ of customers who had experience dealing for more than 5 years.

These results re-affirm the importance of Syari'ah bank established a good image. Not that Syari'ah bank that had been operating for 25 years as long as this did not indicate CIRA good, but this period was not long enough to be used as the basis for a good image measurement. The assertion that a good image could be developed to provide a good service, good service would form a good image that strengthens customer trust. Furthermore, the trust would satisfy our customers and became the foundation for the formation of customer loyalty

\subsection{The Effect of Image on Customer Satisfaction}

This study provided empirical evidence that the image did not have a significant effect on customer satisfaction. Banking is a service business whose intangible, customers did not know what would be received prior to paying the price of the transaction. Therefore, customers would look for something that could be used as collateral to ensure that they would receive something (services) as expected. Banking image could be used as a guarantee that the bank would give you something good, which could be seen from the management, the quality of bids, profit (profit sharing) was given, communication, innovation, customer orientation, and others (Peters, 2007). Various administration was done continuously and could prove a lot of people in the long term. The study stated that the image of Syari'ah banking did not have an impact on customer satisfaction and loyalty. In fact, some previous research had supported this research model that better corporate image influenced on satisfaction and customer loyalty.

Islamic banking companies might work to improve its image as a bank that actually run the Islamic law and professional work in order to grow, so that the public's view of Syari'ah banking could be improved overall. On the other hand, Islamic banking products offered to the potential market should be able to move people's desire to be willing to do a purchase decision on bank products offered. The role of the marketing department was very high for the achievement of consumers' purchasing decisions, despite the fact that promotional obligations was the duty of all member banks. With the success of the sales of the products offered, then the image of Syari'ah banking product was better.

With the image of the movement bank were improving, then at a certain side effect would look good corporate image on customer satisfaction and customer loyalty. Syari'ah bank's image had not yet been tested, the customer could not make it as a guarantee that the services provided would be as they expected. Therefore, the image was directly not give effect to 
customer satisfaction, even there was a negative effect on the image of customer satisfaction. This meant that if the bank did not improve its image Syari'ah would be lower customer satisfaction. The effect became significant if mediated by the trust of customers.

The influence of the image on customer satisfaction has been investigated by Fouzia (2012), Rasheed \& Aimin (2012), Raza et.al (2012), and Ghafoor \& Azhar (2014). Of the three studies, the results of the study Fouzia Ali, Raza et.al, and Ghafoor \& Azhar limited to providing results that the image including one determinant of bank customer satisfaction, while Rasheed \& Aimin (2012) to prove their influence on customer satisfaction image. The yield difference was caused by: (a) Differences in the analytical techniques used where a previous study using multiple linear regression techniques, whereas in this study using SEM; (b) The development of Syari'ah Bank in Pakistan (the location of a previous study) had a longer history than the Syari'ah bank in Indonesia.

The findings could be used as a guide to perform image enhancement. The main determinant of the image was the quality of service. Based on interviews with respondents, syari'ah bank rated slow to provide services. In the discussion of the services, syari'ah bank also considered to have a limited branch unit and ATM locations. ATM Syari'ah banks also joined by conventional banks, BNI ATM had become one with Syari'ah BNI, BRI ATM had become one with syari'ah BRI, and Mandiri ATM had become one with the Syari'ah Mandiri so that Syari'ah bank ATM impressed "ride" the conventional banks. This led to less prestigious Syari'ah bank.

Based on interviews with Syari'ah banking officials, judging from the variety of products, Syari'ah bank was still dominant in murabahah transactions and not many offered a range of other products that are generally interested in conventional banks. That's why without amendment the Syari'ah bank customers might move to other banks that were rated more allocate financial and nonfinancial.

\subsection{The Effect of Image on Customer Loyalty}

The last empirical evidence found in this study was that, the image did not have a significant effect on consumer loyalty, even a negative effect. This meant that if no improvement on the elements rated shaping the image of the loyalty would decrease. Linked to the findings of research on the image of syari'ah bank, customers rate the service and the products were not better in Syari'ah bank, the name of Syari'ah bank was not prestigious, and customers tended to switch to conventional banks. The cause impressions was disloyal bank customers Syari'ah proven in customer loyalty variables that found that bank customers Syari'ah would not advise people to choose a bank syari'ah, the client was not willing to explain differences in Syari'ah banks and conventional banks, as well as would complain if served not as expected.

Previous research on the effect of the image on customer loyalty had been done by Hamdani (2014) and Abduh (2015), two studies gave different results, ie, there was the effect of image on customer loyalty. Differences in results might occur due to the use of different analysis techniques. Hamdani (2014) used multiple linear regression analysis, while this study used SEM. The difference with the results Abduh (2015), the research done in Kuwait with the 
number of respondents doubled (600 customers) than in this study (250 customers). An interesting finding, customers in research Abduh was 595 people (99.2\%) only deal in Syari'ah bank. Image had no effect on customer loyalty, but when mediated by the image turns satisfaction effect on customer loyalty. These findings suggested that, customers needed to feel satisfaction prior to show loyalty. Things that supported such satisfaction was the service qualityand reliability. Thus the Syari'ah bank needed to improve its service quality so that the customers were satisfied to then became loyal.

\section{Conclusion}

The findings of this study revealed that the service quality and reliability had significantly influence customer satisfaction and loyalty Syari'ah bank, while the image did not affect the bank customers' satisfaction and loyalty and trust Syari'ah also had no significant effect on customer loyalty Syari'ah bank. These results raised a number of implications for managerial practice in syari'ah banking management as followed:

First, Syari'ah banking services in Indonesia still had a fairly large potential market. The ability to work on the market should be done with appropriate strategic approach targeted segments. Substantially, the bank developed the principle that syari'ah bank was the transaction for the results. It provided a tremendous impact on the development of various businesses which in turn would provide an important significance in the formation of prosperity. However, the difficulty of this endeavor developed Syari'ah bank (it was because the reasons not yet maximal the market and market characteristics that did not mandate) then to attract market faster response Syari'ah banks appear as "follower" of conventional banks. This measure could further weaken the position of syari'ah bank. Therefore Syari'ah Banks still had constancy with principal businesses, profit sharing. Effort was always redesigning and communicate the core business should always be a priority step. Internally Syari'ah bank should reassert the main business of this, the socialization of this understanding was not only done externally, it was more important to first perform internally.

Second, both in the development of the main business and banking Syari'ah complementary business still put the service quality as the key to business success, because it could provide positive implications for the establishment of trust, satisfaction, and loyalty. Service quality included several dimensions (tangible, reliability, responsiveness, assurance, and empathy) that as a whole might be evaluated and improved in accordance with the demands of customers and the environment. Tangible dimension (the location of the branch and ATM locations unit) complained of customers could be made accessible. To ensure the efficiency of the distribution of the location of branches and ATMs unit might be in accordance with market breadth. Perumnas area, Plaju, and Jakabaring looked to be a potential area that had not worked. Expansion of the market meant ongoing socialization through communications programs for commercial and non-commercial use. Non-commercial communication should be prioritized to reduce costs by developing a positive story of mouth. Positive story developed through reliability, responsiveness, assurance, and empathy given to customers through the transaction experience. 


\section{References}

Abduh, M., \& Alibaad, A. (2015). Factors influence customer loyalty in kuwait islamic banks: An exploratory study. Journal of Islamic Economics, Banking and Finance, 11(3), 167-178. https://doi.org/10.12816/0024454

Ahmed, K. (2011). Online Service Quality and Customer Satisfaction : A Case Study of Bank Islam Malaysia Berhad. MPRA PaperNo.30782, posted 22, September 2011, 05:20 UTS (online) (https://mpra.ub.uni-muenchen.de/30782/2/MPRA-paper-30782.pdf)

Ashraf, M. G. (2015). Include the position of islamic banking, service quality, satisfaction, trust and loyalty in the context of in integrated model for Islamic finance. European Journal of Business and Management.

Badara, M. S., Mat, N. K., Mujtaba, A. M., Al-Refai, A. N., Badara, A. M., \& Abubakar, F. M. (2013). direct effect of service quality dimension on customer satisfaction and customer loyalty in Nigerian Islamic Bank. Management, 3(1), 6-11.

Bitner, M. J., \& Zeithaml, V. A. (2003). Service Marketing. New Delhi: McGraw Hill

Butt, M. M., \& Aftab, M. (2012). Incorporating attitude toward halal banking in an integrated sevice quality, satisfaction, trust, and loyalty model in online islamic banking context. 2012. International Journal of Banking Marketing, 31(1), 6-23.

https://doi.org/10.1108/02652321311292029

Darmansyah. (2011). Pengaruh total service quality terhadap kepuasan nasabah pada bank syari'ah di Bengkulu. Jurnal Aplikasi Manajemen, 10(4), 868-879.

Dimitriades, Z. S. (2006). Customer satisfaction, loyalty and commitment in service organization some evidence from Greece. Management Research News, 29(12), 782-800. https://doi.org/10.1108/01409170610717817

Dowling, G. R. (1994). Corporate Reputations: Strategies for Developing the Corporate Brand. London: Kogan Page

Edvardsson, B., Johnson, M. D., Gustafsson, A., \& Strandvik, T. (200). The effect of satisfaction and loyalty on profits and growth: Product versus services. Total Quality Management, 11, S917-S927. https://doi.org/10.1080/09544120050135461

Engel, J. F., Blackwell, R. D., \& Minard, P. W. (2012). Consumer Behavior. Singapore: Cengage Learning Asia Pte Ltd.

Fouzia, A. (2011). Customer satisfaction and islamic banking in Pakistan. International Journal of Asian Social Science, 1(4), 89-96.

Gee, R., Coates, G., \& Nicholson, M. (2008). Understanding and profitably managing customer loyalty. Marketing Intelligence and Planning, 26(4), 359-374.

https://doi.org/10.1108/02634500810879278

Griffin, J. (2007). Customer Luyalty: How to Earn It, gow to keep it. New York, USA: 
Lexington Books

Gronroos, C. (2000). Service Management and Marketing: A Customer Relationship Management Approach. West Sussex: John Wiley \& Sons Ltd.

Guranyameh, P. (2015). The effect of factors affecting customers' acceptance of internet banking based on their initial trust. Journal of Applied Environmental and Biological Sciences, 5(12S), 344-352.

Hamdani, S. M. K. (2014). The system in islamic banking in termsoft customer satisfaction in Pakistan. IOSR Journal of Business and Management, 16(1), 102-106.

https://doi.org/10.9790/487X-1615102106

Hidayat, R., Akhmad, S., \& Machmud, M. (2015). Effects of service quality, customer trust and customer religious commitment on customer satisfaction and loyalty of Islamic Banks in East Java. Al-Iqtishad, 7(2), 151-164. https://doi.org/10.15408/ijies.v7i2.1681

Hoyer, W. D., \& Maclnnis, D. J. (2001). Consumer Behavior. Boston: Houghton Mifflin Company

Kashif, M., Wan, S. S., Rehman, M. A., \& Sarifuddin, S. (2015). Customer satisfaction and loyalty in Malaysian Islamic Banks: A PAKSERV Investigation. International Journal of Bank Marketing, 33(1), 23-40. https://doi.org/10.1108/IJBM-08-2013-0084

Khafafa, A. J., \& Shafii, Z. (2013). Customer satisfaction and Islamic banking awareness in the Islamic Banking window system in Libya. Middle-East Journal of Science Research, 13, 12-17.

Khalid, S., Mahmood, B., Abbas, M., \& Hussain, S. (2011). Customer satisfaction with service quality in conventional banking In Pakistan: The case of Faisalabad. International Journal of Marketing Studies, 3(4), 165-173. https://doi.org/10.5539/ijms.v3n4p165

Kheng, L. L., Muhammad, O., Ramayah, T., \& Musahab, R. (2010). The impact of servive quality on customer loyalty: A study of banks in Penang Malaysia. International Journal of Marketing Studies, 2(2), 57-66. https://doi.org/10.5539/ijms.v2n2p57

Kishada, Z. M. E. M., \& Wahab, N. A. (2013). Factors affecting customer loyalty in islamic banking: Evidence from Malaysian Banks. International Journal of Businessand Social Science, 4(7), 264-273.

Kotler, P., \& Keller, K. L. (2016). Marketing Management. England: Pearson Education Limited.

Madjid, R. (2015). Explaining customer satisfaction with experience, customer trust and commitment in Syariah Banks Kendari City. The International Journal of Engineering and Science, 4(4), 51-59.

Malhotra, N. K. (2007). Marketing Research. New Jersey: Prentice Hall. https://doi.org/10.1108/S1548-6435(2007)3 


\section{Macrothink}

Business and Economic Research ISSN 2162-4860 2019, Vol. 9, No. 1

Misbach, I., Hadiwidjojo, S. D., \& Armanu. (2013). Islamic bank service quality and trust: Study on Islamic Bank in Makassar Indonesia. International Journal of Business Management, 8(5), 48-61. https://doi.org/10.5539/ijbm.v8n5p48

Mollering, G. (2006). Trust: Reason, Routine, Reflexivity. Oxford: Elsevier.

Munawar, K. M. (2014). Impact of service quality on customer satisfaction and customer loyalty: Evidence from banking sector. Pakistan Journal of Commerce and Social Science, $8(2), 331-354$.

Munusamy, J., Chelliah, S., \& Mun, H. W. (2010). Service quality delivery and its impact on customer satisfaction in the banking sector in Malaysia. International Journal of Innovation, management and Technology, 1(4), 398-404.

Nayebzadeh, S., Jalaly, M., \& Shamsi, H. M. (2013). The relationship between customer satisfaction and loyalty the bank performance in Iran. International Journal of Academic Research in Business and Social Science, 3(6), 114-124.

Nunnaly, J. C. (1978). Psychometric Theory. New York: McGraw Hill

Parasuraman, A., Zeithmal, V. A., \& Berry, L. L. (1988). SERQUAL- a multiple-item scale for measuring consumeer perception of Service Quality. Journal of Retailing, 64(1), 12-40.

Rahmani, L., Firoozbakht, Z., \& Taghipoor, A. (2014). Service quality, relationship quality, and customer loyalty (Case Study: Banking Industry in Iran). Open Journal of Social Science.

Ramdhani, M. A., Ramdhani, A., \& Kurniati, D. M. (2011). The influence of service quality toward customer satisfaction ofislamic sharia Bank. Australian Journal of Basic and Applied Science, 5(9), 1099-1104.

Rasheed, H., \& Aimin, A. (2012). An evaluation of bank customer satisfaction in pakistan, case of conventional banks. International Journal of Businessand Social Science, 3(16), 73-77.

Raza, A., Saddique, U., Farooq, U., Awan, S., \& Amin, S. (2012). Customer's satisfaction towards islamic banking: Pakistan's perspective. Arabian Journal of Business and Mangement Review, 1(6), 71-79.

Rizwan, M., Yaseen, G., Nawaz, A., \& Hussain, L. (2014). Incorporating attitude towards islamic banking in an integrated service quality, satisfaction, trust, and loyalty model. International Journal of Accounting and Financial Reporting, 4(2), 456-477.

https://doi.org/10.5296/ijafr.v4i2.6585

Robbins, S. P., \& Judge, T. A. (2009). Organizational Behavior.New York: Prentice Hall Jersey.

Sabir, R. I., Ghafoor, O., Akhtar, N., Hafeez, I., \& UrRehman, A. (2014). factor affecting customer satisfaction in banking sector of Pakistan. International Reviewof Management and Business Research, 3(2), 1014-1025. 


\section{Macrothink}

Business and Economic Research

ISSN 2162-4860

2019, Vol. 9, No. 1

Saeed, R., Iqbal, A., Lodhi, R. N., Sami, A., Riaz, A., Munir, M., \& Muzna. (2014). The impact of service quality on customer loyalti in islamic banking sector of Pakistan: A mediating role of customer satisfaction. Journal of Basic and Apllied Science Research, 4(2), 135-143.

Sanjuq, G. (2014). The impact of service quality on customer satisfaction in the banking sector in Riyadh, Saudi Arabia. International Journal of Business Administration, 5(4), 77-84. https://doi.org/10.5430/ijba.v5n4p77

Schiffman, L., \& Kanuk, L. L. (2008). Consumer Behavior. Jakarta: PT Indeks.

Siddiqi, K. O. (2011). interrelation between service quality attributes, customer satisfaction and customer loyalty in the retail banking sector in Bangladesh. International Journal of Business and Management, 6(3), 12-35. https://doi.org/10.5539/ijbm.v6n3p12

Spector, A. J. (2005). Basic Dimension of the Corporate Image. Journal of Marketing, 25(6), 47-51. https://doi.org/10.1177/002224296102500608

Sunaryo. (2013). Relationship Service to Muslim Customer Loyalty in Islamic Banking: Satisfaction as Mediator. Asia-Pacific Management and Business Application. https://doi.org/10.21776/ub.apmba.2013.002.01.5

Warsito, C. (2015). The image of financial institution an islamic bank in mediation service quality and customer satisfaction on customer loyalty in Purwokerto. Al-Iqtishad, 7(2), 217-228. https://doi.org/10.15408/ijies.v7i2.1699

\section{Copyright Disclaimer}

Copyright for this article is retained by the author(s), with first publication rights granted to the journal.

This is an open-access article distributed under the terms and conditions of the Creative Commons Attribution license (http://creativecommons.org/licenses/by/3.0/). 